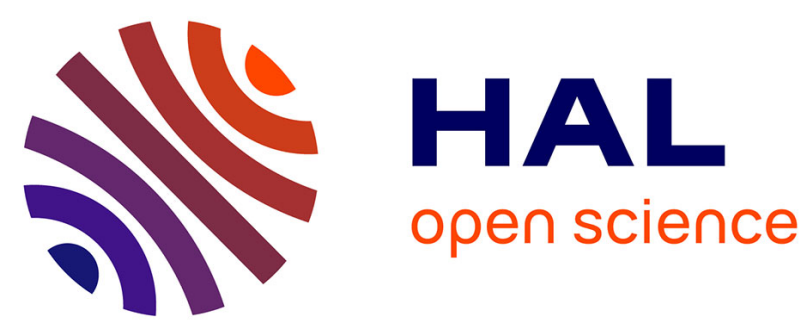

\title{
Mechanism of formation of lysozyme crystals in concentrated ammonium sulfate solution from concentration profiles and equilibria: influence of the 2nd osmotic virial coefficient
}

\author{
Fabienne Espitalier, Yu Chia Cheng, Abraham M. Lenhoff
}

\section{To cite this version:}

Fabienne Espitalier, Yu Chia Cheng, Abraham M. Lenhoff. Mechanism of formation of lysozyme crystals in concentrated ammonium sulfate solution from concentration profiles and equilibria: influence of the 2nd osmotic virial coefficient. Powder Technology, 2009, 190 ( $\left.\mathrm{n}^{\circ} 1-2\right)$, p.112-117. 10.1016/j.powtec.2008.04.085 . hal-01845772

\author{
HAL Id: hal-01845772 \\ https://hal.science/hal-01845772
}

Submitted on 5 Sep 2018

HAL is a multi-disciplinary open access archive for the deposit and dissemination of scientific research documents, whether they are published or not. The documents may come from teaching and research institutions in France or abroad, or from public or private research centers.
L'archive ouverte pluridisciplinaire HAL, est destinée au dépôt et à la diffusion de documents scientifiques de niveau recherche, publiés ou non, émanant des établissements d'enseignement et de recherche français ou étrangers, des laboratoires publics ou privés. 


\title{
Mechanism of formation of lysozyme crystals in concentrated ammonium sulfate solution from concentration profiles and equilibria: Influence of the 2nd osmotic virial coefficient
}

\author{
F. Espitalier ${ }^{\mathrm{a}, *}$, Y.C. Cheng ${ }^{\mathrm{b}}$, A.M. Lenhoff ${ }^{\mathrm{b}}$ \\ a RAPSODEE, UMR CNRS 2392 Ecole des Mines d'Albi-Carmaux, France \\ ${ }^{\mathrm{b}}$ University of Delaware, Newark, DE 19716 USA
}

\begin{abstract}
A B S T R A C T
We have modelled the nucleation of the orthorhombic crystal form of lysozyme and subsequent crystal growth from concentration profiles established during the measurement of equilibrium in concentrated solutions of ammonium sulphate. A BCF mechanism for the crystal growth has been assumed. The second osmotic virial coefficient is used to calculate the activity coefficient of the protein in solution. A steep decrease of $B_{22}$ is predicted for salt molalities higher than $6.8 \mathrm{~m}$.
\end{abstract}

\section{Keywords:}

Moment of population

Protein

Crystallization

Second virial coefficient

\section{Introduction}

During the determination of the solid-liquid phase diagram for lysozyme/ammonium sulfate solutions, the concentration profiles of lysozyme after the mixing of protein and ammonium sulfate solutions have been measured for salt molalities ranging between 3 and $8.5 \mathrm{~m}$ at $\mathrm{pH} 8$ and $25^{\circ} \mathrm{C}[1,2]$. The concentration decreases very quickly initially to attain a first plateau (in a few seconds). At this point two phases are in equilibrium: a liquid containing ammonium sulfate, water and protein, and a solid (dense) phase containing amorphous protein, water and ammonium sulfate. After some hours, the concentration begins to decrease toward a second plateau. During the second decrease in concentration, a crystal phase detected by X-ray analysis is formed. At the end of the experiment, the supernatant concentration is assumed to be equal to the equilibrium solubility of the crystal phase (orthorhombic structure). Three phases are present in the vessel: crystal phase, dense phase and liquid phase. Two types of experiments have been performed. At low molality $(I<5.5 \mathrm{~m})$, only a crystal phase is formed. At high molality $(I>5.5 \mathrm{~m})$ an amorphous phase appears immediately, and after a few hours the crystal phase is formed.

The aim of this study is to try to understand the mechanism of formation of the crystal phase and model it. The classical theories of nucleation and growth have been used. The knowledge of the kinetics of lysozyme crystallization provides information that can aid in understanding the interactions involved during crystallization and permits identification of favourable crystallization conditions for the design of large scale crystallization processes.

\footnotetext{
* Corresponding author.

E-mail address: fabienne.espitalier@enstimac.fr (F. Espitalier).
}

\section{Model}

\subsection{Nucleation and growth rates}

Solution of the population and mass balances permits calculation of the concentration profile as a function of time. The population balance has been written in terms of the moments of distribution; equations in terms of the normalized moments are given in the Appendix. Solution of these equations requires knowledge of the supersaturation ratio $S$ and the nucleation and growth rates of the crystal phase ( $J$ and $G$ ).

In the following calculations, the crystals are considered to be spherical in shape.

The nucleation rate $J$ has been calculated using [3]:

$J=z f^{*} C_{0} \exp \left(-\frac{\Delta G^{*}}{k_{\mathrm{B}} T}\right)$

with $\Delta G^{*}$ the critical free enthalpy, $\Delta G^{*}=\frac{16 \pi v_{0}^{2} \sigma^{3}}{3\left(k_{\mathrm{B}} T\right)^{2} \ln ^{2} S}, z$ the Zeldovich factor, $z=\left(\frac{W^{*}}{3 \pi k_{\mathrm{B}} T\left(n^{*}\right)^{2}}\right)^{1 / 2} \cdot f^{*}$ is the monomer attachment frequency, which can be described, for attachment controlled by volume diffusion, by $f_{\text {diffusion }}{ }^{*}=\left(48 \pi^{2} v_{0}\right)^{1 / 3} D C_{\mathrm{eq}}^{\prime} S n^{* 1 / 3}$, and, for attachment controlled by interfacial transfer, by $f_{\text {interface }}{ }^{*}=\left(6 \pi^{2} v_{0}\right)^{1 / 3} D C_{\mathrm{eq}}^{\prime} S n^{* 2 / 3}$ with $C_{0}$ the concentration of nucleation sites, $C_{\mathrm{eq}}^{\prime}$ the equilibrium molar concentration of protein, $D$ the diffusion coefficient of the protein in the medium, $T$ the temperature, $n^{*}$ the number of molecules in the critical cluster, $v_{0}$ the molecular volume of the protein in the solid phase, and $\sigma$ the crystal/solution surface energy.

A Burton-Cabreara-Frank (BCF) mechanism has been chosen to describe the crystal growth. The growth rate $G$ is expressed by $G=$ $\frac{K_{\mathrm{sc} 1}}{K_{\mathrm{sc} 2}}(S-1)^{2} \tan h\left(\frac{K_{\mathrm{sc} 2}}{(S-1)}\right)$ where $K_{\mathrm{sc} 2}$ is a function of surface energy, temperature, diameter of the growth units, number of cooperating spirals 
Table 1

B22 values, growth rate parameters from $\sigma=-K\left(\frac{k_{\mathrm{B}} T}{\left(d_{0} / 2\right)^{2}}\right) \ln \left(\frac{\phi_{\mathrm{s}}}{m}\right)$ for the surface energy, and mean volume diameters

\begin{tabular}{|c|c|c|c|c|}
\hline \multirow[t]{2}{*}{ Parameters } & \multicolumn{2}{|c|}{$\begin{array}{l}\text { Frequency of monomer } \\
\text { attachment: Control by } \\
\text { diffusion }\end{array}$} & \multicolumn{2}{|c|}{$\begin{array}{l}\text { Frequency of monomer } \\
\text { attachment: Control by } \\
\text { interfacial transfer }\end{array}$} \\
\hline & $\begin{array}{l}\text { With } \\
\text { amorphous } \\
\text { phase }\end{array}$ & $\begin{array}{l}\text { Without } \\
\text { amorphous } \\
\text { phase }\end{array}$ & $\begin{array}{l}\text { With } \\
\text { amorphous } \\
\text { phase }\end{array}$ & $\begin{array}{l}\text { Without } \\
\text { amorphous } \\
\text { phase }\end{array}$ \\
\hline$K_{\mathrm{SC} 1}(\mathrm{~m} / \mathrm{h})$ & $4.46910^{-8}$ & $1.24010^{-7}$ & $3.20910^{-8}$ & $7.34010^{-8}$ \\
\hline$K_{\mathrm{SC} 2}$ & 0.385 & 0.3490 & 0.3420 & 0.3457 \\
\hline K & 0.0492 & $\begin{array}{l}0.0492 \\
d(4,3)(\mu \mathrm{m})\end{array}$ & 0.050 & 0.050 \\
\hline$I=5.8 \mathrm{~m}$ & & 6.2 & & 3.8 \\
\hline
\end{tabular}

and $K_{\mathrm{sc} 1}$ of temperature, retardation factor during adsorption of the growth unit into a kink site in the step, shape of the spiral, number of growth units per unit volume of solution and activation energy of dehydratation.

The supersaturation ratio has been calculated by the classical expression, $S=\frac{\gamma^{\perp} C^{\prime}}{\gamma_{\mathrm{eq}}^{\mathrm{L}} C_{\mathrm{eq}}{ }^{\prime}}$.

The activity coefficient of the protein has been expressed in terms of the osmotic virial coefficients [4]

$\ln \gamma^{\mathrm{L}}=2 B_{22} C^{\prime}+\frac{3}{2} B_{222} C^{\prime 2}+0\left(B_{2222} C^{\prime 3}\right) \approx 2 B_{22} C^{\prime}$

where $C^{\prime}$ is the protein molar concentration and the standard state for the protein is taken such that $\gamma^{\mathrm{L}} \rightarrow 1$ as $C^{\prime} \rightarrow 0, B_{22}$ and $B_{222}$ are the second and third osmotic virial coefficients respectively. In a dilute solution, binary interactions are much more probable than ternary interactions so it usually suffices to examine only interaction involving pairs of particles. When $B_{22}$ is negative, the net interaction between protein molecules is attractive and when $B_{22}$ is positive, the net interaction is repulsive.

Combining the equations for activity coefficients and supersaturation ratio gives an estimate of the thermodynamic driving force for crystallization:

$S=\exp \left|\ln \left(\frac{C}{C_{\mathrm{eq}}}\right)+2 B_{22} M_{\text {protein }}\left(C-C_{\mathrm{eq}}\right) W_{\text {water }} \rho_{\text {solution }}\right|$

with $C$ the concentration of protein expressed in molality (kg protein/ $\mathrm{kg}$ water), $M_{\text {protein }}$ the molar weight of protein, $w_{\text {water }}$ the weight fraction of water in the solution and $\rho_{\text {solution }}$ the density of the solution.

\subsection{Model assumptions}

In the model, we have assumed that:

- One parameter permits description of the surface energy for experiments in the presence or absence of the amorphous phase. The surface free energy can be expressed in terms of the interactions between protein molecules [5]. In the case of low solubility, the authors proposed

$\left.\sigma=-K \frac{k_{\mathrm{B}} T}{\left(d_{0} / 2\right)^{2}}\right) \ln \left(\frac{\phi_{\mathrm{s}}}{m}\right)$

where $K$ is a constant function of the stacking of molecules in the crystal lattice $z$ (for instance, $K=0.042$ for $z=6$ ), $\phi_{\mathrm{s}}$ is the volume

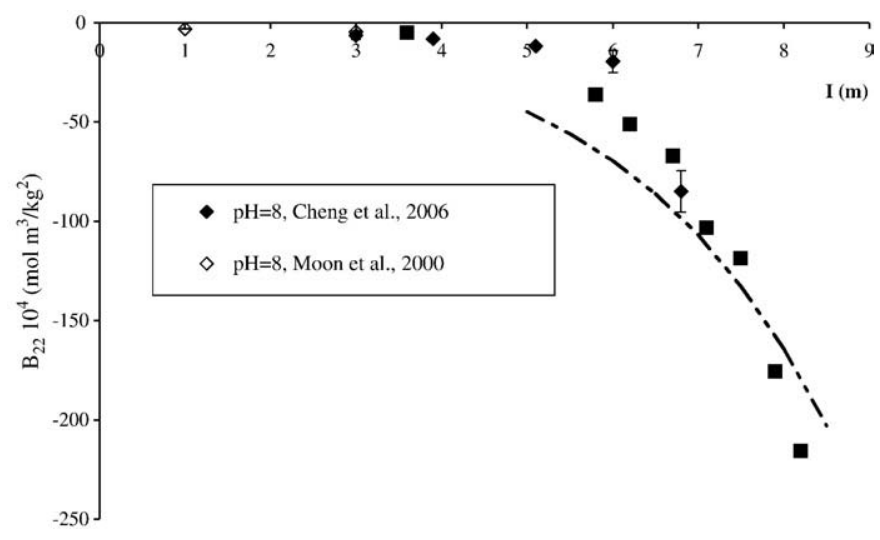

Fig. 1. Evolution of the measured second osmotic virial coefficients ( $\diamond$ and $\diamond$ ) as a function of the molality (parameter values in Table 1 ), the calculated second osmotic virial coefficients from crystallization model $(\boldsymbol{\square})$, and the calculated second osmotic virial coefficients from the correlation of Haas et al. [6] with $A=1.47 \cdot 10^{-5}$ and $z=2(----)$.

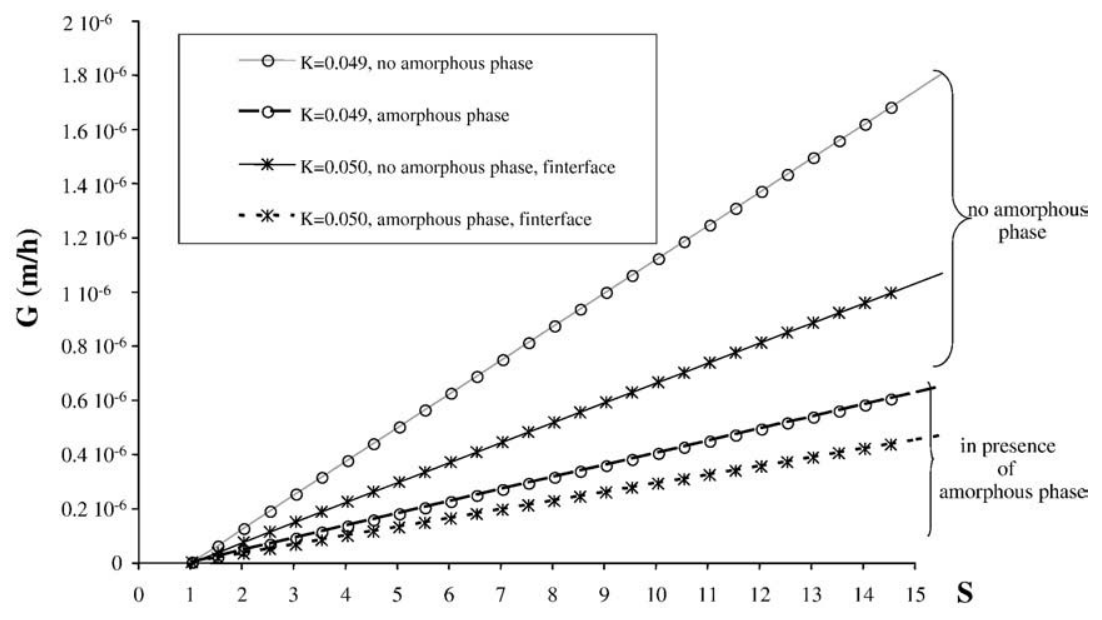

Fig. 2. Growth rate with and without amorphous phase as function of supersaturation ratio. 
(a)
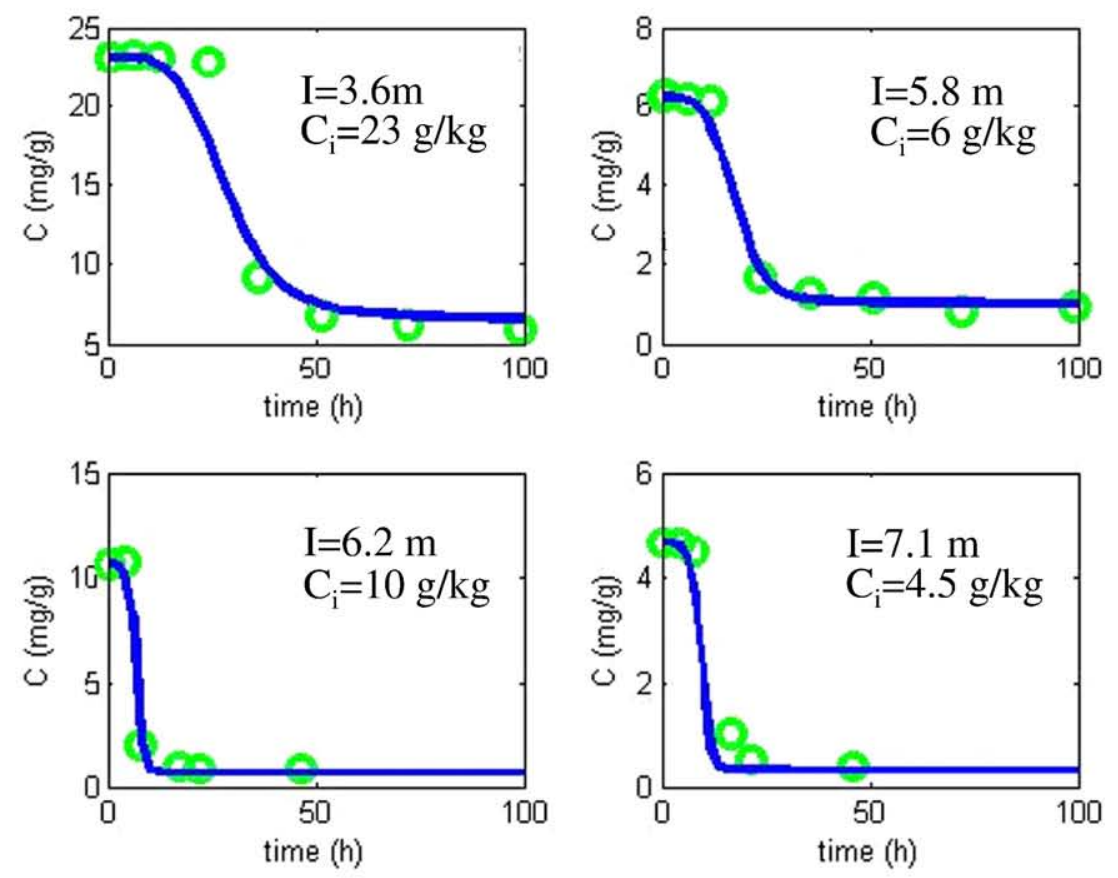

(b)

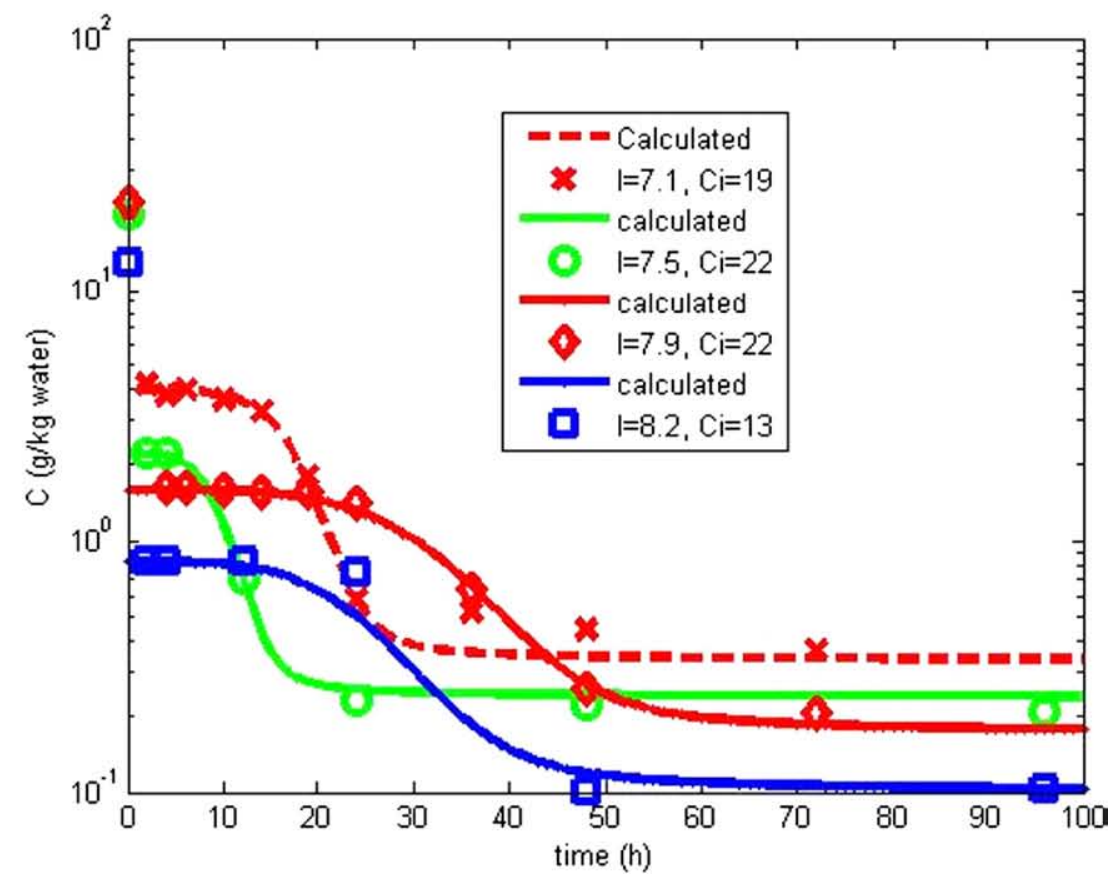

Fig. 3. Concentration profiles with $K=0.0492$, frequency of monomer attachment control by diffusion (a) without amorphous phase and (b) in presence of amorphous phase at different molalities $I(\mathrm{~m})$ and initial protein concentration $C_{i}(\mathrm{~g} / \mathrm{kg})$ (points are experimental values and continuous lines are calculated values).

fraction of protein in the liquid phase at equilibrium, $\mathrm{m}$ is the number of lattices sites occupied by a protein molecule $\left(=M_{\text {protein }} / M_{\text {water }} /\right.$ $\left.\rho_{\text {protein }} \cdot \rho_{\text {water }}\right)$ and $d_{0}$ is the diameter of a protein molecule. The volume fraction of protein in the liquid phase at equilibrium decreases as the salt concentration increases, as the ratio $\left(\frac{\phi_{s}}{m}\right)$ is lower than 1 : the surface energy crystal/solution increases when the molality increases.

- The growth rate does not depend on salt concentration (same $K_{\mathrm{SC} 1}$ and $K_{\mathrm{SC} 2}$ for all experiments) but is modified in the presence of amorphous phase.
- The amorphous phase does not modify the nucleation rate (primary nucleation), so the amorphous phase is assumed inert with respect to nucleation in these calculations.

For molalities higher than $7 \mathrm{~m}$, experimental values of $B^{22}$ are not available because of experimental difficulties, so we have chosen to estimate the missing values of $B^{22}$.

Therefore the number of fitted parameters is 10: one parameter for the nucleation rate, two parameters for the growth rate without 
amorphous phase, two parameters for the growth rate in the presence of amorphous phase, and five virial coefficients with eleven independent concentration profiles.

The minimized function is:

$f=\sum_{k=1}^{N_{\text {experiment }}} \sum_{j=1}^{N_{\text {point }}} \frac{\left\{C_{\text {experimental }}(j, k)-C_{\text {calculated }}(j, k)\right\}^{2}}{\text { variance }(j, k) C_{\text {calculated }}(j, k)^{2}}$

The variance $(j, k)$ represents the errors on each point $j$ during the experiment $k$ estimated from replicating experiments conducted at the same operating conditions.

The parameter estimation has been done in two steps. During the first step, only experiments in the presence of the amorphous phase are taken into account. One parameter for the nucleation rate $K$ (constant necessary to calculate the surface energy), two parameters for the growth rate in the presence of amorphous phase and six virial coefficients have been fitted with six independent concentration profiles. Different initial guesses were used for each of these parameters in order to verify that the same optimum was found in each case.

The second step makes it possible to estimate the two parameters for the growth rate in the absence of the amorphous phase as well as two virial coefficient values; four independent concentration profiles obtained in the absence of amorphous phase were used for this purpose. Again different initial guesses were tested.

\section{Results}

The values of the nucleation and growth rate parameters, and the constant $K$ used to calculate the surface energy, are shown in Table 1. Two assumptions for the frequency of monomer attachment are considered. Modification of this law modifies the final size of the crystals: if the frequency of monomer attachment is the limiting step, the mean diameter is higher $(6.2 \mu \mathrm{m}$ instead of $3.8 \mu \mathrm{m})$.

The values of $K$ ( 0.049 or 0.050 for attachment controlled by diffusion or by interfacial transfer respectively) are close to the value of 0.042 proposed by Haas and Drenth [5] for a coordination number of 6 and range between 0.042 for a cubic lattice and 0.066 for a bodycentred cubic lattice. The volume-mean diameter $d_{43}$ obtained for $K=0.049$ is $6.2 \mu \mathrm{m}$ at the end of the experiment $(I=5.8 \mathrm{~m})$. This size seems to be in better agreement with the experimental value than the $92 \mu \mathrm{m}$ obtained by not considering the activity coefficient in the calculation of the supersaturation ratio (results not shown).

The calculated second virial coefficients are reported in Fig. 1 as a function of the ionic strength $I$. The net interaction between molecules is attractive and this net interaction increases steeply with the molality. In Fig. 1, a simple model potential for interaction between protein molecules, $B_{22} \frac{4}{M_{\text {protein }} \rho_{\text {protein }}}\left[1-A\left\{\left(\frac{\phi_{\mathrm{s}}}{m}\right)^{-2 / z^{\prime}}-1\right\}\right]$, proposed by Haas et al. [6], is plotted. In this relation, $Z^{\prime}$ is the coordination number of a molecule in the crystal matrix and $A$ is a parameter depending on anisotropy $\mathrm{p}$ and on the range of the interactions $(a(\lambda-1))$. Biswal et al. [7] showed structure data for orthorhombic lysozyme and give a coordination number of 4 . So the correlation with $A=0.033$ has been chosen because the fit presents the lowest relative calculated mean error of $12 \%$ for $I$ higher than $7 \mathrm{~m}$ (the calculation is done with $M_{\text {protein }}=14,000 \mathrm{~g} / \mathrm{mol}$ and $\left.\rho_{\text {protein }}=1260 \mathrm{~kg} / \mathrm{m}^{3}\right)$. The virial coefficient values seem to follow a reasonable trend based on conditions for which the values could in fact be measured. So although the number for adjustable parameters is high, the results show the plausibility of the model structure.

The values of growth rate are reported in Fig. 2. The difference in the value of the parameter $K_{\mathrm{sc} 2}$ with and without dense phase present is small (maximum $9 \%$ ) in comparison with the variation of $K_{\mathrm{sc} 1}$. In both cases, the calculated growth rates in the presence of amorphous phase are lower. This behaviour can be explained by a modification of the coefficient $K_{\mathrm{sc} 1}$ due to a change in composition of the supernatant.
Moreover, in these calculations, the amorphous phase has been considered to be inert. Simple dissolution of the amorphous phase would imply that the growth rate found is an apparent growth rate.

Fig. 3(a) presents the calculated concentration profiles obtained for different salt concentrations (ammonium sulfate $3.6<I<7.1 \mathrm{~m}$ ) and with different initial protein concentration at $\mathrm{pH} 8$ and $298 \mathrm{~K}$ in the absence of the amorphous phase. Fig. 3(b) presents the concentration profiles obtained for higher salt concentrations $(I>7 \mathrm{~m})$ at $\mathrm{pH} 8$ and $298 \mathrm{~K}$ with formation of the amorphous phase. The experimental points are also shown in each figure.

The concentration profiles calculated with the model provide good agreement with the experimental concentration profiles for $K=0.0492$ (Fig. 3). These results are presented in term of the supersaturation ratio in Fig. 3. The concentration or the supersaturation ratio profiles depend on the supersaturation ratio (which influences nucleation and growth rates) and on the ionic strength (which influences surface energy).

The model allows calculation of an energy surface ranging between 0.8 and $1.2 \mathrm{~mJ} / \mathrm{m}^{2}$ (Fig. 4). Our values of surface energy are in agreement with the values of surface energy calculated for lysozyme in sodium chloride solution (between 2 and $7 \% \mathrm{NaCl}$ ) from an expression for the Gibbs free energy of an aqueous protein solution [8].

Some complementary experiments have been performed in order to validate the model in the absence of dense phase in the medium. The concentration profiles corresponding to these different experiments

(a)

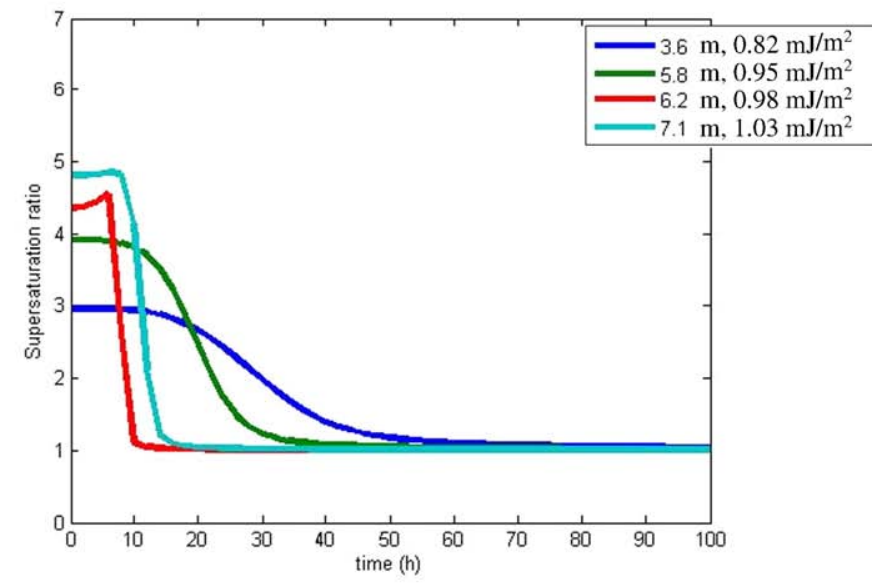

(b)

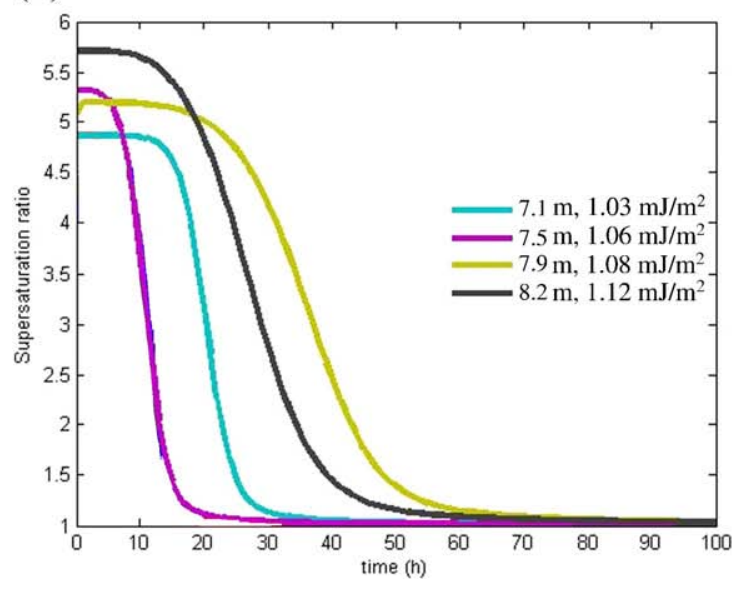

Fig. 4. Supersaturation ratio profiles with $K=0.0492$, used to calculate the frequency of monomer attachment control by diffusion at different molalities $I(\mathrm{~m})$; the calculated surface energy is also indicated. (a) Without amorphous phase. (b) In presence of amorphous phase. 
(a)

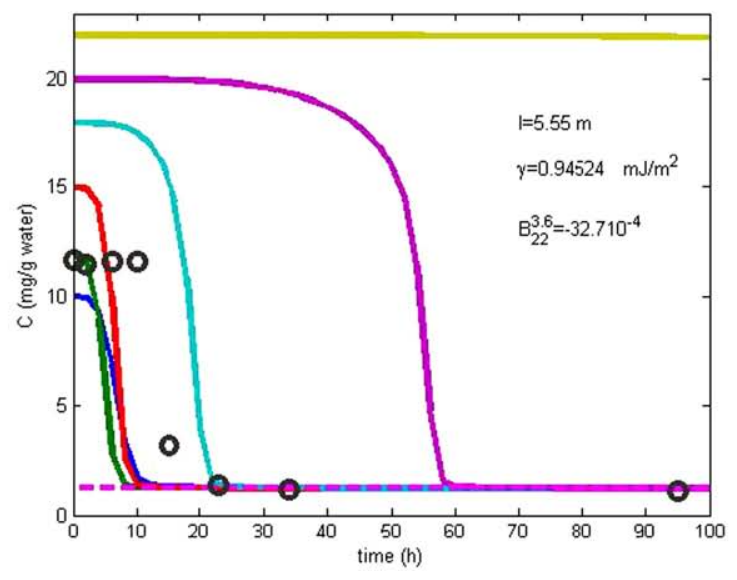

(b)

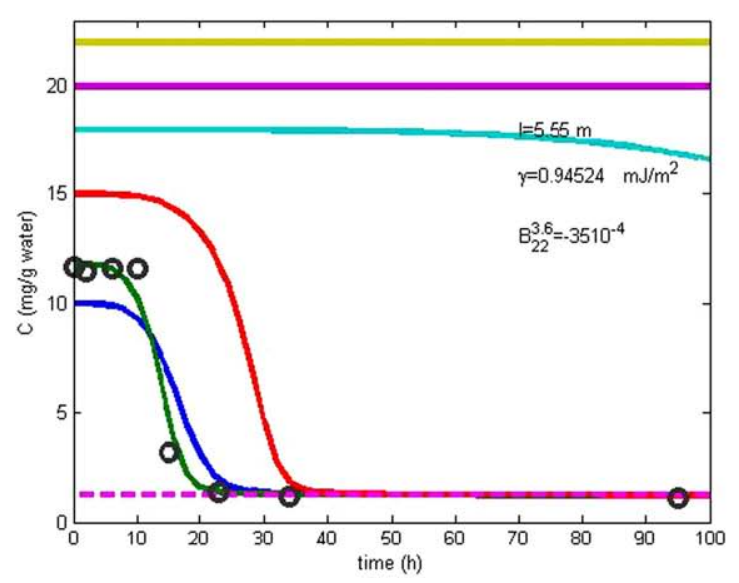

Fig. 5. Calculated and experimental concentration profiles at $5.5 \mathrm{~m}$. (a) $B_{22}=-32.71 \cdot 10^{-4} \mathrm{~mol} \mathrm{ml} / \mathrm{g}^{2}$ value interpolated between 3.6 and $5.8 \mathrm{~m}$. (b) $B_{22}$ adjusted at $-35 \cdot 10^{-4} \mathrm{~mol} \mathrm{~m} / \mathrm{g}^{2}$ $(-7 \%)$. Mean volume diameter $d(4,3)$ at $100 \mathrm{~h}=4.6 \mu \mathrm{m}$.

have been calculated for the case in which the frequency of monomer attachment is controlled by diffusion; the experimental points are reported as well (Fig. 5). Initially the value of $B_{22}$ was interpolated between the values at ionic strengths of 3.6 and $5.8 \mathrm{~m}$. However, for all experiments except that at $3.6 \mathrm{~m}$, good agreement between the experimental and calculated profiles required $B_{22}$ to be adjusted. The relative differences between the two values of $B_{22}$ are reported in the caption of Fig. 5, which shows only the results at $5.5 \mathrm{~m}$, in terms of concentration profiles for different initial concentrations. Interestingly, for given $B_{22}$, surface energy and growth parameters, crystallization seems possible only for a finite range of concentration due to the change in the supersaturation ratio when the initial concentration is increased.

The supersaturation ratio increases and decreases because of the product of $\ln \left[C / C_{\mathrm{eq}}\right]$ and of the term $\left[2 B_{22} M_{\text {protein }}\left(C-C_{\mathrm{eq}}\right) W_{\text {water }} \rho_{\text {solution }}\right]$ for a given concentration $C$. When the difference $\left(C-C_{\text {eq }}\right)$ increases, $\ln$ $\left[C / C_{\text {eq }}\right]$ increases but $\left[2 B_{22} M_{\text {protein }}\left(C-C_{\text {eq }}\right) W_{\text {water }} \rho_{\text {solution }}\right]$ decreases due to the negative value of $B_{22}$. In this case, the maximum concentration to induce crystallization is below $20 \mathrm{~g} / \mathrm{kg}$ water. This window of crystallization can explain why the crystalline phase does not appear despite the high initial ratio $C / C_{\text {eq }}$ used in the experiments where the amorphous phase appears. Formation of the crystal phase is possible only because of the formation of the metastable phase (amorphous protein), which leads to a decrease of the concentration $C$. Crystallization becomes possible when $C$ reaches the window for crystallization.

\section{Conclusion}

In this study we have investigated the nucleation of orthorhombic crystals of lysozyme and their subsequent growth from concentration profiles established during the measurement of the equilibrium concentration in concentrated solutions of ammonium sulphate.

We have shown that the second decrease in concentration observed in the concentration profiles can be explained by homogeneous nucleation of the crystal phase and growth of crystals formed (the dense phase is assumed inert). It seems that the supersaturation ratio can not be calculated by the classical hypothesis of $\frac{\gamma^{L}}{\gamma^{L}} \rightarrow 1$ in organic solution because of the strong protein-protein interăctions. The use of this assumption induces a large dispersion in the overall growth rate. In order to take into account the ratio of activity coefficients in the supersaturation ratio, the second osmotic virial coefficient $B_{22}$ has been used. Because of experimental difficulties, it is not possible to measure $B_{22}$ for molalities higher than $6.8 \mathrm{~m}$ ionic strength, so these values have been fitted with two parameters for the growth rate and one parameter for the surface energy.
A sharp decrease in the fitted value of $B_{22}$ is observed for molalities higher than $6.8 \mathrm{~m}$. Moreover, the behaviour of $B_{22}$ seems to be correctly represented by the law of Haas et al. [5].

The overall growth rate seems to be in agreement with the face growth rate found in the literature. Two different overall growth rates have been identified with or without dense phase with the two laws for the surface energy. It seems that in the presence of the dense phase, the overall growth rate decreases at constant supersaturation. This result can be explained by dissolution of the amorphous phase. Preliminary dissolution experiments show that the dissolution is not the sole cause of the decrease in the growth rate.

\section{Nomenclature}

$a_{i} \quad$ activity coefficient of species $i(-)$

A parameter (-)

$B_{22} \quad$ osmotic second virial coefficient $\left(\mathrm{mol} \mathrm{m} / \mathrm{kg}^{2}\right)$

C protein mass concentration $(\mathrm{kg} / \mathrm{kg}$ water)

$C_{\mathrm{eq}} \quad$ protein mass concentration at saturation $(\mathrm{kg} / \mathrm{kg}$ water $)$

$C^{\prime} \quad$ protein molar concentration $\left(\mathrm{mol} / \mathrm{m}^{3}\right)$

$D \quad$ diffusion coefficient of protein molecule $\left(\mathrm{m}^{2} / \mathrm{s}\right)$

$d_{\mathrm{c}} \quad$ critical diameter of nucleus $(\mathrm{m})$

$d_{0} \quad$ molecular diameter $(\mathrm{m})$

$d(1,0) \quad$ mean number diameter $(\mathrm{m})$

$d(4,3) \quad$ mean volume diameter $(\mathrm{m})$

$f^{*} \quad$ monomer attachment frequency $\left(\mathrm{s}^{-1}\right)$

G overall growth rate $(\mathrm{m} / \mathrm{s})$

$J \quad$ nucleation rate $\left(1 / \mathrm{m}^{3} / \mathrm{s}\right)$

$K \quad$ constant for the calculation of the surface energy (-)

$K_{\mathrm{SC} 1} \quad$ BCF growth rate parameter $(\mathrm{m} / \mathrm{s})$

$K_{\mathrm{SC} 2} \quad$ BCF growth rate parameter (-)

$k_{\mathrm{B}} \quad$ Boltzmann constant $(\mathrm{J} /$ molecule $/ \mathrm{K})$

$M_{\text {protein }}$ molar mass of protein $(\mathrm{kg} / \mathrm{mol})$

$M_{\text {water }} \quad$ molar mass of water $(\mathrm{kg} / \mathrm{mol})$

$n^{*} \quad$ work necessary for the formation of a nucleus $(\mathrm{J})$

$P \quad$ constant for the calculation of the surface energy (-)

$S \quad$ supersaturation ratio (-)

$T \quad$ temperature $(\mathrm{K})$

$t$ time (s)

$V_{\mathrm{m}} \quad$ molar volume of protein $\left(\mathrm{m}^{3} / \mathrm{mol}\right)$

$w_{\text {water }} \quad$ weight fraction of water (-)

$W^{*} \quad$ work necessary for the formation of a nucleus $(\mathrm{J})$

$Z \quad$ Zeldovitch factor (-)

$Z^{\prime} \quad$ the coordination number of a molecule in the crystal matrix 


\section{Greek letters}

$\alpha \quad$ volume shape factor (-)

$\beta \quad$ volume shape factor $(-)$

$\gamma \quad$ surface energy crystal/solution $\left(\mathrm{J} / \mathrm{m}^{2}\right)$

$\mu_{0} \quad$ moment of order $0(-)$

$\mu_{1} \quad$ moment of order $1(\mathrm{~m})$

$\mu_{2} \quad$ moment of order $2\left(\mathrm{~m}^{2}\right)$

$\mu_{3} \quad$ moment of order $3\left(\mathrm{~m}^{3}\right)$

$\mu_{4} \quad$ moment of order $4\left(\mathrm{~m}^{4}\right)$

$\mu_{i} \quad$ chemical potential of species $i(\mathrm{~J} / \mathrm{mol})$

$\theta \quad$ dimensionless time $(-)$

$v_{0} \quad$ molecular volume $\left(\mathrm{m}^{3}\right)$

$\mu_{k} \quad$ dimensionless moment of order $\mathrm{k}(-)$

$\rho \quad$ density $\left(\mathrm{kg} / \mathrm{m}^{3}\right)$

$\rho_{\mathrm{c}} \quad$ density of solid $\left(\mathrm{kg} / \mathrm{m}^{3}\right)$

$\rho_{\text {protein }}$ density of protein $\left(\mathrm{kg} / \mathrm{m}^{3}\right)$

$\rho_{\text {solution }}$ density of solution $\left(\mathrm{kg} / \mathrm{m}^{3}\right)$

$\rho_{\text {water }} \quad$ density of water $\left(\mathrm{kg} / \mathrm{m}^{3}\right)$

\section{Subscript}

eq equilibrium

\section{Superscript \\ L liquid}

\section{Appendix A. Population balance normalized equations}

The population balance equations written in terms of moments have been normalized using

$\theta=\frac{G_{0}}{L_{0}} t ; \mu_{0}=\frac{\mu_{0}}{N_{0}} ; \mu_{1}=\frac{\mu_{1}}{L_{0}} ; \mu_{2}=\frac{\mu_{2}}{S_{0}} ; \mu_{3}=\frac{\mu_{3}}{V_{0}} ; \mu_{4}=\frac{\mu_{4}}{Q_{0}}$ and $S=\frac{C}{C^{*}}$

For the calculation of $N_{0}, L_{0}, S_{0}, V_{0}$, and $Q_{0}$, the total weight per $\mathrm{kg}$ of water that can be crystallized $\left(C_{i}-C^{*}\right)$ has been chosen as a reference:

$N_{0}=\frac{\left(C_{i}-C^{*}\right) 10^{-3}}{\alpha \rho_{\mathrm{c}} d_{\mathrm{c} 0}^{3}}$ $d_{\mathrm{co}}$ is the critical diameter of the nucleus at the initial supersaturation ratio, $C_{i}$ being the initial concentration.

$L_{0}=N_{0} d_{\mathrm{c} 0} ; S_{0}=N_{0} d_{\mathrm{c} 0}^{2} ; V_{0}=N_{0} d_{\mathrm{c} 0}^{3} ; Q_{0}=N_{0} d_{\mathrm{c} 0}^{4}$

$\frac{\mathrm{d} \mu_{0}}{\mathrm{~d} \theta}=\frac{J}{\rho W_{\text {ater }}} \frac{L_{0}}{G_{0} N_{0}}$

$\frac{\mathrm{d} \mu_{1}}{\mathrm{~d} \theta}=N_{0}\left(\frac{G}{G_{0}} \mu_{0}+\frac{d_{c}}{L_{0}} \frac{\mathrm{d} \mu_{0}}{\mathrm{~d} \theta}\right)$

$\frac{\mathrm{d} \mu_{2}}{\mathrm{~d} \theta}=N_{0}\left(2 \frac{G}{G_{0}} \mu_{1}+\frac{d_{\mathrm{c}}^{2}}{S_{0}} \frac{\mathrm{d} \mu_{0}}{\mathrm{~d} \theta}\right)$

$\frac{\mathrm{d} \mu_{3}}{\mathrm{~d} \theta}=N_{0}\left(3 \frac{G}{G_{0}} \mu_{2}+\frac{d_{\mathrm{c}}^{3}}{V_{0}} \frac{\mathrm{d} \mu_{0}}{\mathrm{~d} \theta}\right)$

$\frac{\mathrm{d} \mu_{4}}{\mathrm{~d} \theta}=N_{0}\left(4 \frac{G}{G_{0}} \mu_{3}+\frac{d_{\mathrm{c}}^{4}}{Q_{0}} \frac{\mathrm{d} \mu_{0}}{\mathrm{~d} \theta}\right)$

The normalized mass balance equation is:

$\frac{\mathrm{d} S}{\mathrm{~d} \theta}=-\left(S_{\text {init }}-1\right) \frac{d \mu_{3}}{d \theta}$

\section{References}

[1] J.J. Moretti, S.I. Sandler, A.M. Lenhoff, Phase equilibria in the lysozyme-ammonium sulfate-water system, Biotechnol. Bioeng. 70 (5) (2000) 498-506.

[2] Y.C. Cheng, R.F. Lobo, S.I. Sandler, A.M. Lenhoff, Kinetics and equilibria of protein precipitation and crystallization in concentrated ammonium sulfate solutions, Biotechnol. Bioeng. 94 (2006) 177-188.

[3] D. Kashchiev, G.M. Van Rosmalen, Review: nucleation in solution revisited, Cryst. Res. Technol. 38 (7) (2003) 555-574.

[4] M.L. Grant, Effects of thermodynamic nonideality in protein crystal growth, J. Cryst. Growth 209 (2000) 130-137.

[5] C. Haas, J. Drenth, The interaction energy between two protein molecules related to physical properties of their solution and their crystals and implications for crystal growth, J. Cryst. Growth 154 (1995) 126-135.

[6] C. Haas, J. Drenth, W.W. Wilson, Relation between the solubility of proteins in aqueous solutions and the second virial coefficient of the solution, J. Phys. Chem. B 103 (1999) 2808-2811.

[7] B.K. Biswal, N. Sukumar, M. Vijayan, Hydration, mobility and accessibility of lysozyme: structures of a $\mathrm{pH} 6.5$ orthorhombic form and its low-humidity variant and a comparative study involving 20 crystallographically independent molecules, Acta Cryst. D56 (2000) 1110-1119.

[8] C. Haas, J. Drenth, The interface between a protein crystal and an aqueous solution and its effects on nucleation and crystal growth, J. Phys. Chem. B 104 (2000) 368-377. 